\section{Cold Temperature Tolerance of Trunk and Root Tissues in One- or Two-year-old Apple Rootstocks}

\author{
Renae E. Moran ${ }^{2}$, Youping Sun $\mathbf{1}$, Fang Geng, and Donglin Zhang \\ Department of Plant, Soil and Environmental Sciences, University of Maine, \\ P.O. Box 179, Monmouth, ME 04259
}

\section{Gennaro Fazio \\ Plant Genetics Resources Unit, USDA-ARS, Geneva, NY 14456}

Additional index words. Malus $\times$ domestica, controlled freezing, cold hardiness, tissue browning, $\mathrm{LT}_{50}$

\begin{abstract}
Winter injury to the root systems of fruit trees can cause significant tree losses and yield reductions in the northern regions of the United States and Canada. To compare the root and trunk cold temperature tolerance, a series of experiments were conducted using ungrafted apple rootstocks. 'Geneva ${ }^{\circledR} 11$ ' (G.11), 'Geneva ${ }^{\circledR} 30$ ' (G.30), 'Geneva ${ }^{\circledR}$ 41' (G.41), 'P.2', and 'Budagovsky 9' (B.9) apple (Malus $\times$ domestica Borkh.) rootstocks had root tissue hardiness similar to 'M.26', but 'Geneva® 935' (G.935) had greater cold-hardiness than M.26 when based on shoot regrowth in ungrafted trees. The $\mathrm{LT}_{50}$ of $\mathrm{M} .26$ and P.2 roots ranged from -12 to $-14^{\circ} \mathrm{C}$. The $\mathrm{LT}_{50}$ was $-13^{\circ} \mathrm{C}$ for $\mathrm{B.9},-13.4$ to $-14.6^{\circ} \mathrm{C}$ for $\mathrm{G} .30$, and $-12{ }^{\circ} \mathrm{C}$ for $\mathrm{G.11}$. The $\mathrm{LT}_{50}$ of $\mathrm{G} .41$ was one of the highest in one experiment, $-8{ }^{\circ} \mathrm{C}$, and one of the lowest in another, colder than $-15.0{ }^{\circ} \mathrm{C}$. The $\mathrm{LT}_{50}$ of G.935 roots was the lowest and ranged from -16 to $-19^{\circ} \mathrm{C}$. Compared with M.26, trunk cold-hardiness in December was greater in B.9 and P.2 and was similar in G.30. Coldhardiness of G.11 in December was mixed with less injury in the xylem but more injury in the phloem compared with M.26. In October, M.26 and G.935 trunks had little injury after exposure to $-24^{\circ} \mathrm{C}$.
\end{abstract}

Apple roots have limited ability to acclimate to cold temperatures (Wildung et al., 1973) and can be injured by temperatures below $-8{ }^{\circ} \mathrm{C}$ (Embree, 1988). Cold-hardiness is the ability to tolerate subfreezing temperatures without injury to living plant cells. In the northern regions of the United States and Canada, cold temperature injury to the root systems of fruit trees can cause significant tree losses and yield reductions and occurs periodically when snow cover is thin or nonexistent (Czyncsyk, 1979; Wildung et al., 1973). Symptoms of root injury become evident the next spring when trees "leaf out" followed by wilting and death of new growth in severe cases and stunted shoot growth in less severe

Received for publication 26 July 2011. Accepted for publication 25 Aug. 2011.

Funded in part by the Maine Agricultural Center, the International Fruit Tree Association, and the New England Tree Fruit Growers Research Committee.

Maine Agricultural and Forest Experiment Station number 3227.

Mention of a trademark, proprietary product, or vendor does not constitute a guarantee or warranty of the product nor does it imply approval or disapproval to the exclusion of other products or vendors that may also be suitable.

${ }^{1}$ Current address: School of Agricultural, Forest, and Environmental Sciences, Clemson University, Clemson, SC 29634.

${ }^{2}$ To whom reprint requests should be addressed; e-mail rmoran@maine.edu. cases. When significant tree losses occur, replanting is the only option causing substantial financial losses for the grower. Rootstocks with greater cold-hardiness can prevent economic losses caused by cold temperature injury to the root system.

Most commercial orchards in the United States are planted to Malling rootstocks that lack cold-hardiness or tolerance of subfreezing temperatures (Embree, 1988) and B.9, which has greater cold-hardiness (Quamme and Brownlee, 1997). Based on controlled studies and tree survival under natural conditions, M.26 and B.9 are rated as moderately cold-hardy (Privé and Embree, 1997; Quamme and Brownlee, 1997; Wildung et al., 1973), but have other weakness such as disease susceptibility. Geneva rootstocks have been selected for disease resistance, size control, and precocity making them ideally suited for apple production (Autio et al., 2010; Cummins and Aldwinkle, 1974), but their cold-hardiness has not been evaluated under controlled conditions. As more orchards are planted to Geneva rootstocks, information will be needed on their levels of cold-hardiness to determine their suitability for planting in regions with cold winters.

Cold temperature injury to the trunk can also cause tree mortality in fall when severe freezing temperatures occur during the acclimation stage (Caprio and Quamme, 1999) and is more likely than injury during midwinter in some regions (Quamme et al., 2010). Previous studies indicate that M.26 has greater trunk cold-hardiness than 'M.M.106' and 'M.7' in November (Embree, 1988) but a similar level of shoot tissue cold-hardiness (Wildung et al., 1973). Based on observations in field trials, 'Geneva ${ }^{\circledR} 16$ ' (G.16) may be more susceptible to cold temperature injury in the fall (Robinson et al., 2005). New rootstocks need to be tested for cold-hardiness in trunk tissues.

Test winters do not always occur during the course of field trials, which necessitates controlled studies for a more rapid determination. The objective of this research was to measure the cold-hardiness of selected Geneva rootstocks in controlled conditions.

\section{Materials and Methods}

All experiments were conducted at the Maine Agricultural and Forest Experiment Station in Monmouth, ME, which is located at latitude $44^{\circ} \mathrm{N}$ and longitude $-70^{\circ} \mathrm{W}$

Expt. 1. In May 2007, ungrafted M.26 and G.935 rootstocks, with a trunk diameter of $0.6 \mathrm{~cm}$, were planted in pots with pasteurized field soil, sand, and calcined montmorillonite clay (Turface, Buffalo Grove, IL) mixed at a ratio of 2:2:1 by volume. Trees were watered as needed and did not require any pest control measures. Trees were fertilized twice with a complete fertilizer containing $18.8 \mathrm{mg}$ nitrogen, $38 \mathrm{mg} \mathrm{P}_{2} \mathrm{O}_{5}, 18.8 \mathrm{~g} \mathrm{~K}_{2} \mathrm{O}, 2.5 \mathrm{mg}$ boron, $8.8 \mathrm{mg}$ copper, $0.2 \mathrm{mg}$ iron, $0.08 \mathrm{mg}$ zinc, and $0.06 \mathrm{mg}$ manganese per tree at each time. Mean air temperature from May to October was $17.0^{\circ} \mathrm{C}$. Trees were grown in pots outdoors until late October when they were placed in cold storage at a temperature of $0{ }^{\circ} \mathrm{C}$ until analysis in February.

Root systems were compared for injury incurred after exposure to temperatures ranging from -8 to $-16^{\circ} \mathrm{C}$ and an unfrozen control. The media were rinsed off roots before freezing. The root systems were wrapped in moist paper towels and placed in plastic bags, which provided a rapid and uniform drop in temperature (Privé and Embree, 1997). Freezing of whole plants was conducted using a programmable freezer (SuperCold Freezer 40-9.4; ScienTemp, Adrian, MI) and a temperature decrease of $2{ }^{\circ} \mathrm{C}$ per hour. Temperature of the root systems was measured with type $\mathrm{T}$ thermocouples and a Campbell Scientific CR-10 data logger (Campbell Scientific, Logan, UT). Trees were held at each set temperature for $60 \mathrm{~min}$, removed from the freezer, and placed in an insulated cooler overnight. Trees were planted in pots with peat, coir, perlite, and bark mix media (Metro-Mix 560 ${ }^{\mathrm{TM}}$ with Coir; Sun Gro, Vancouver, British Columbia, Canada). At planting, trees were pruned back to 12 $\mathrm{cm}$ and placed in a heated greenhouse to assess recovery from cold temperature injury based on the amount of shoot growth. Internal tissues were inspected for symptoms of cold temperature injury at the point where they were pruned. One new shoot was allowed to grow with all others removed. After 2 months, new shoots were removed from trees and dried in an oven at $70^{\circ} \mathrm{C}$ for 1 week and then weighed. The experiment was replicated 12 times with single trees as the experimental unit. 
Expt. 2. In May 2008, ungrafted trees of M.26, G.935, and G.41 were planted at a spacing of $25 \mathrm{~cm}$ outdoors in field soil covered with black plastic. The soil was a Dixfield fine sandy loam, coarse-loamy, mixed frigid typic Haplothords. G.935 trees were 1 year older than the other two rootstocks. Trunk diameter of G.41 and M.26 was $0.6 \mathrm{~cm}$ and was $1.5 \mathrm{~cm}$ in G.935 trees. Trees were grown in this and subsequent experiments without irrigation or fertilizer and did not need pest control measures. Mean air temperature from May to October was $17.0^{\circ} \mathrm{C}$. Trees were dug in late October, planted in sand, and stored at $5{ }^{\circ} \mathrm{C}$ until analysis in February.

Injury to the root systems was compared after exposure to temperatures ranging from -9 to $-21^{\circ} \mathrm{C}$ and an unfrozen control. Temperature was decreased at a rate of $3{ }^{\circ} \mathrm{C}$ per hour. Methods were otherwise similar to Expt. 1.

Trunk cold-hardiness of M.26 and G.935 rootstocks was measured in late October by exposing trees to temperatures of -6 to $-24^{\circ} \mathrm{C}$. Whole trees were exposed to freezing temperatures in the same manner as in Expt. 1. Injury was measured as visual browning of the xylem and phloem at a trunk height of $6 \mathrm{~cm}$ above and below the soil line. A rating scale of 0 to 5 was used with 0 indicating no browning and 5 indicating dark browning throughout the tissue. Because root systems were also exposed to freezing temperatures, tree survival was not measured. The experiment was replicated six times with single trees as the experimental unit.

Expt. 3. In June 2009, ungrafted trees of G.11, G.30, G.41, B.9, and P.2 with a trunk diameter of $0.6 \mathrm{~cm}$ were planted at a spacing of $25 \mathrm{~cm}$ outdoors in field soil covered with black plastic. M.26 trees were planted in the previous year. Mean air temperature from May to October was $16.1^{\circ} \mathrm{C}$. Trees were dug in late October, planted in sand, and stored at $1{ }^{\circ} \mathrm{C}$ until analysis in early December and February.

Injury to the root systems was compared after exposure to temperatures ranging from -10 to $-24{ }^{\circ} \mathrm{C}$ and an unfrozen control. Temperature was decreased at a rate of $3{ }^{\circ} \mathrm{C}$ per hour. One $\mathrm{d}$ after exposure to treatment temperatures, injury was measured as browning of the belowground portion of the trunk internally and external browning of the root system. Browning in the trunk was measured by cutting off the lower $3 \mathrm{~cm}$ of the shank to expose internal tissues. The entire root system was rated as a whole without cutting into individual roots. A rating scale of 0 to 5 was used with 0 indicating no browning and 5 indicating dark browning. Methods were otherwise similar to Expt. 1. The experiment was replicated four times with single trees as the experimental unit.

Trunk cold-hardiness of M.26, G.11, G.30, B.9, and P.2 rootstocks was measured in Dec. 2009 by exposing trees to temperatures of -15 to $-27^{\circ} \mathrm{C}$, whereas roots were insulated in peat media and Styrofoam. A 1-cm-thick layer of foam insulation was placed over the peat media for additional protection from severe temperatures. When air temperature reached $-27^{\circ} \mathrm{C}$, temperature of the peat media ranged from -1 to $-6{ }^{\circ} \mathrm{C}$. The experiment was replicated five times with single trees as the experiment unit.

After freezing, trees were held at cool, nonfreezing temperatures overnight and then placed in cold storage at $1{ }^{\circ} \mathrm{C}$ until May at which time they were brought outdoors. One new shoot per tree was allowed to grow 2 months at which time it was removed from the tree for dry weight measurement. Coldhardiness of the trunk was measured 1 week after temperature treatment by assessing visual browning. Browning of the xylem, phloem, and cambium was assessed at a trunk height of 10 and $25 \mathrm{~cm}$ above the soil line. Internal tissues were exposed by cutting lengthwise at each point. A rating scale of 0 to 5 was used with 0 indicating no browning and 5 indicating severe browning. Percentage of the xylem cross-sectional area with browning was also visually estimated. The experiment was replicated five times with single trees as the experimental unit.

Expt. 4. In 2010, ungrafted trees of M.26 and G.935 trees with a trunk diameter of $0.64 \mathrm{~cm}$ were planted at a spacing of $25 \mathrm{~cm}$ outdoors in field soil covered with black plastic. G.30, G.41, B.9, and P.2 trees were planted the previous year. Mean air temperature from May to October was $18.4{ }^{\circ} \mathrm{C}$. Trees were dug in late October, planted in sand, and stored at $1{ }^{\circ} \mathrm{C}$ until analysis in February.
Injury to the root systems was compared after exposure to temperatures ranging from -10 to $-18{ }^{\circ} \mathrm{C}$ and an unfrozen control. As a result of an insufficient number of trees, G.41 was exposed to temperatures in the range of -10 to $-15^{\circ} \mathrm{C}$. Temperature was decreased at a rate of $3{ }^{\circ} \mathrm{C}$ per hour. Methods were otherwise similar to Expt. 1. The experiment was replicated five times, except for G.41, which had two replications. Single trees were the experiment unit.

Shoot dry weight and tissue browning data were analyzed as a completely randomized design using the PROC GLM procedure with means separation by LSMEANS (SAS Institute, Cary, NC). Shoot dry weight was converted to percentage of the unfrozen control to eliminate variation resulting from shoot length differences between rootstocks. Tree mortality was considered as relative shoot dry weight of $20 \%$ or less. Tree mortality data were analyzed using the PROC PROBIT procedure and inverse confidence limits to estimate the $\mathrm{LT}_{50}$.

\section{Results}

Expt. 1. After exposure to treatment temperature, shoots of G.935 began growing 1 week earlier than M.26 and were larger at the end of the experiment. Shoot dry weight in M.26 control trees was $2.7 \mathrm{~g}$ compared with $4.8 \mathrm{~g}$ for G.935. Root tissue was damaged by

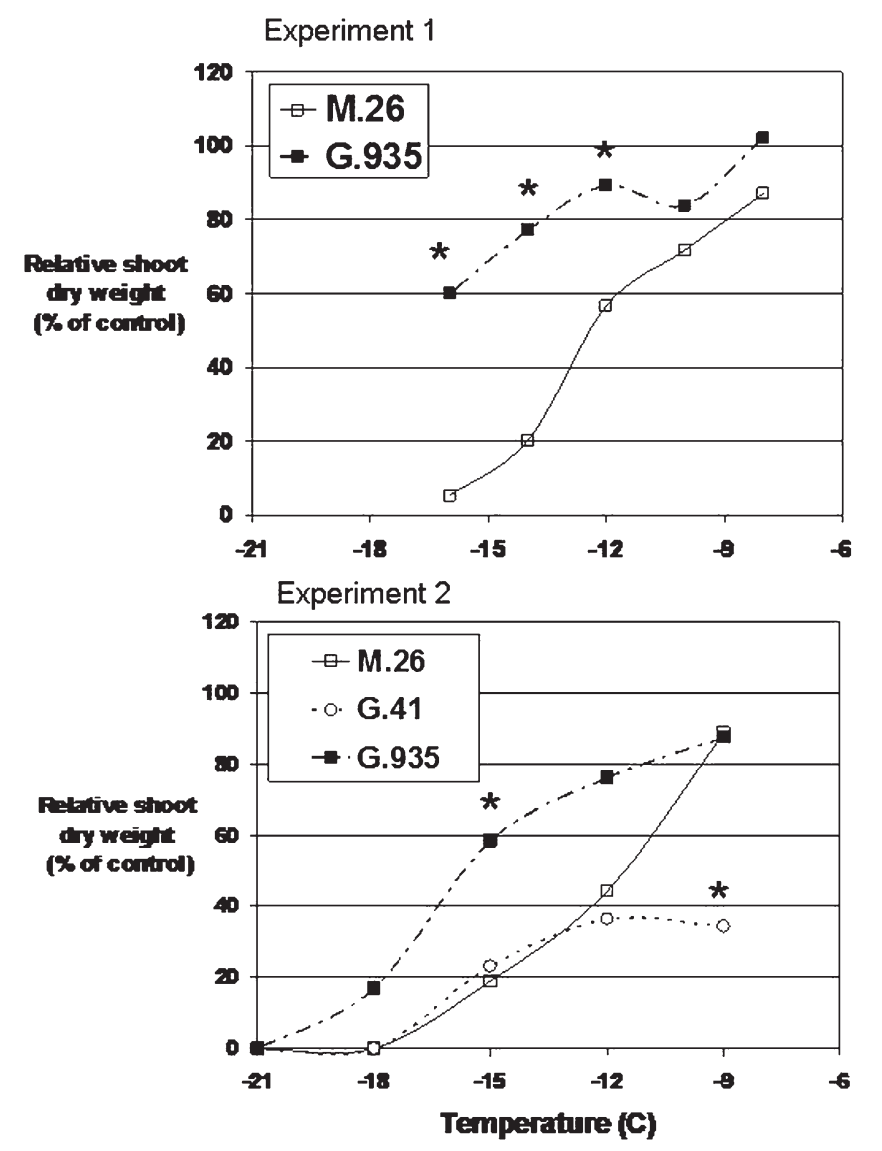

Fig. 1. Relative shoot growth of apple rootstocks following exposure of whole trees to temperatures of -8 to $-16{ }^{\circ} \mathrm{C}$ in Expt. 1 and -9 to $-21^{\circ} \mathrm{C}$ in Expt. 2. Shoot growth is expressed as a percentage of the untreated control for each rootstock. *Significant difference from M.26. 
freezing temperatures in both rootstocks with a consequent reduction in shoot growth than G.935 after exposure to temperatures of $-12{ }^{\circ} \mathrm{C}(P=0.0462),-14{ }^{\circ} \mathrm{C}(P=0.0001)$, and $-16{ }^{\circ} \mathrm{C}(P=0.0001)$. Most of the M.26 trees died after exposure to $-16{ }^{\circ} \mathrm{C}$ in contrast to G.935, which had only one tree death. The $\mathrm{LT}_{50}$ for M.26 root tissue was $-13.5^{\circ} \mathrm{C}$, but the $\mathrm{LT}_{50}$ for $\mathrm{G} .935$ could not be estimated because most of the trees survived $-16{ }^{\circ} \mathrm{C}$, the lowest temperature (Table 1).

Expt. 2. In the winter experiment testing root tissue cold-hardiness, shoot dry weight did not vary among untreated trees of M.26, G.935, and G.41 (data not shown). Exposure to $-9{ }^{\circ} \mathrm{C}$ reduced relative shoot growth of G.41 compared with the other two rootstocks $(P=$ 0.0038; Fig. 1). Relative shoot growth of G.41 was similar to M.26 after exposure to -12 , -18 , and $-21{ }^{\circ} \mathrm{C}$. Shoot growth of G.935 was greater than M.26 after exposure to $-15{ }^{\circ} \mathrm{C}$ $(P=0.0545)$ but similar at other temperatures. Tree mortality was $100 \%$ in all rootstocks after exposure to $-21{ }^{\circ} \mathrm{C}$. The lethal temperature for root tissue mortality was lowest for G.935 and highest for G.41 (Table 1).

In the fall experiment measuring trunk cold-hardiness, xylem browning above the (Fig. 1). M.26 had less relative shoot growth

soil line increased as temperature decreased (Table 2). Xylem browning below the soil line was greater in M.26 than in G.935 at temperatures of -9 and $-12{ }^{\circ} \mathrm{C}$, was greater in G.935 at $-21^{\circ} \mathrm{C}$, and was similar in both rootstocks at other temperatures.

Phloem tissue above the soil line had very little browning and no rootstock difference at any temperature. Phloem browning below the soil line increased with decrease in temperature with instances of severe browning occurring at temperatures below $-12{ }^{\circ} \mathrm{C}$ in both rootstocks. Browning was greater in M.26 than G.935 at temperatures of -9 and $-12{ }^{\circ} \mathrm{C}$ but was similar in both rootstocks at colder temperatures.

Expt. 3. In the winter experiment measuring root tissue cold-hardiness, relative shoot growth decreased as temperature decreased from -10 to $-24^{\circ} \mathrm{C}$ and did not differ between rootstocks at any temperature (Fig. 2). None of the trees survived exposure to temperatures of -21 and $-24{ }^{\circ} \mathrm{C}$. The $\mathrm{LT}_{50}$ for root tissue mortality ranged from $-7.8^{\circ} \mathrm{C}$ in $\mathrm{G} .41$ to $-14.1{ }^{\circ} \mathrm{C}$ in M.26 (Table 1).

Internal browning in the trunk below the soil line increased as temperature decreased to $-15^{\circ} \mathrm{C}$ indicating that the belowground portion of the shank is also subject to cold temperature

Table 1. Lethal root temperature $\left({ }^{\circ} \mathrm{C}\right)$ for $50 \%$ tree mortality ${ }^{z}$ after cold temperature injury to apple root tissue.

\begin{tabular}{|c|c|c|c|c|c|c|c|c|}
\hline \multirow{2}{*}{$\begin{array}{l}\text { Root } \\
\text { stock }\end{array}$} & \multicolumn{2}{|r|}{ Expt. 1} & \multicolumn{2}{|r|}{ Expt. 2} & \multicolumn{2}{|r|}{ Expt. 3} & \multicolumn{2}{|r|}{ Expt. 4} \\
\hline & $\mathrm{LT}_{50}$ & $95 \% \mathrm{cl}^{\mathrm{y}}$ & $\mathrm{LT}_{50}$ & $95 \% \mathrm{cl}$ & $\mathrm{LT}_{50}$ & $95 \% \mathrm{cl}$ & $\mathrm{LT}_{50}$ & $95 \% \mathrm{cl}$ \\
\hline M.26 & -13.5 & -12.4 to -15.0 & -13.0 & -11.4 to -15.3 & -14.1 & -10.2 to -16.9 & -11.9 & -2.3 to -14.7 \\
\hline G.935 & $<-16.0^{\mathrm{x}}$ & - & -15.8 & -13.7 to -17.9 & - & - & -18.8 & - \\
\hline G.41 & - & - & -12.1 & -8.6 to -15.5 & -7.8 & 0.0 to -12.0 & $<-15.0^{\mathrm{x}}$ & - \\
\hline G.11 & - & - & - & - & -11.8 & 0.0 to -14.5 & - & - \\
\hline G. 30 & - & - & - & - & -13.4 & -8.9 to -16.2 & -14.6 & -12.3 to -16.9 \\
\hline P. 2 & - & - & - & - & -13.8 & -7.5 to -16.7 & -12.2 & -1.5 to -14.7 \\
\hline B.9 & - & - & - & - & -12.7 & -7.6 to -15.7 & -13.3 & -7.2 to -15.0 \\
\hline
\end{tabular}

${ }^{\mathrm{z}}$ Mortality is based on shoot dry weight of less than or equal to $20 \%$ of the untreated control.

${ }^{\mathrm{y}} \mathrm{cl}=$ confidence limit.

${ }^{\mathrm{x}}$ Not estimated as a result of insufficient tree mortality.

Table 2. Visual browning rating in xylem and phloem tissues above and below the soil line $1 \mathrm{~d}$ after exposure of whole trees to freezing temperatures in late October. ${ }^{2}$

\begin{tabular}{|c|c|c|c|c|c|c|c|}
\hline \multirow[b]{2}{*}{ Rootstock } & \multicolumn{7}{|c|}{ Temperature $\left({ }^{\circ} \mathrm{C}\right)$} \\
\hline & Control & -9 & -12 & -15 & -18 & -21 & -24 \\
\hline \multicolumn{8}{|c|}{ Xylem above the soil line } \\
\hline M.26 & 0.8 & 0.8 & 0.8 & 1.3 & 1.2 & 1.3 & 1.2 \\
\hline G.935 & 0.0 & 0.7 & 0.0 & 0.0 & 0.7 & 0.7 & 0.8 \\
\hline$P^{\mathrm{y}}$ & 0.0240 & NS & 0.0005 & 0.0001 & NS & 0.0493 & NS \\
\hline \multicolumn{8}{|c|}{ Xylem below the soil line } \\
\hline M.26 & 1.0 & 2.0 & 2.0 & 1.3 & 1.3 & 1.0 & 1.5 \\
\hline G.935 & 0.5 & 1.2 & 1.2 & 1.5 & 1.8 & 3.2 & 1.8 \\
\hline$P$ & NS & 0.0005 & 0.0366 & NS & NS & 0.0116 & NS \\
\hline \multicolumn{8}{|c|}{ Phloem above the soil line } \\
\hline M.26 & 0 & 0 & 0 & 0.2 & 0 & 0 & 0.0 \\
\hline G.935 & 0 & 0 & 0 & 0.0 & 0.2 & 0 & 1.0 \\
\hline$P$ & NS & NS & NS & NS & NS & NS & NS \\
\hline \multicolumn{8}{|c|}{ Phloem below the soil line } \\
\hline M.26 & 0 & 0.7 & 0.8 & 3.0 & 1.7 & 2.0 & 2.0 \\
\hline G.935 & 0 & 0.0 & 0.0 & 3.0 & 2.6 & 3.2 & 3.5 \\
\hline$P$ & NS & 0.0101 & 0.0053 & NS & NS & NS & NS \\
\hline
\end{tabular}

${ }^{\mathrm{z} B r o w n i n g}$ was measured at a height of $6 \mathrm{~cm}$ above and below the soil line using a rating scale of 0 to 5 with 0 indicating no browning and 5 indicating dark brown.

${ }^{y}$ Analysis of variance $P$ value for the main effect of rootstock at each temperature.

NS $=$ nonsignificant. injury (Table 3 ). Below $-15^{\circ} \mathrm{C}$, there did not appear to be an increase in browning. At a temperature of $-21{ }^{\circ} \mathrm{C}, \mathrm{B} .9$ and P. 2 had more severe browning than other rootstocks. No rootstock difference occurred at other temperatures. Browning of the root system also increased as temperature decreased and was severe at -18 to $-24^{\circ} \mathrm{C}$. A rootstock difference occurred in the untreated control with P. 2 having a greater degree of browning. At $-18{ }^{\circ} \mathrm{C}$, M.26 had less browning than other rootstocks. Root system browning was more highly correlated with relative shoot dry weight $(r=$ $-0.92, P=0.0001)$ than belowground trunk browning ( $r=-0.55, P=0.0001)$.

In the fall experiment measuring trunk cold-hardiness, aboveground xylem browning increased with decreasing temperatures in M.26, P.2, G.11, and G.30, but not B.9 (Table 4). Phloem browning increased as temperature decreased in B.9 and G.11, but not M.26, G.30, or P.2. Rootstock differences in visual browning occurred at temperatures below $-18{ }^{\circ} \mathrm{C}$. At a temperature of $-21{ }^{\circ} \mathrm{C}$, G.11, B.9, and P.2 had less browning than M.26, whereas G.30 had a similar level of browning as M.26 and G.11. At temperatures of -24 and $-27^{\circ} \mathrm{C}, \mathrm{G} .11$ and G.30 had a similar degree of browning as M.26, but B.9 and P.2 had less. B.9 had natural purple pigmentation in the xylem, which may have obscured slight browning discoloration. Less browning occurred in the lower trunk at $10 \mathrm{~cm}$ above the soil but rootstock differences were similar to what occurred at $25 \mathrm{~cm}$ (data not shown). The amount of xylem cross-sectional area with browning at $25 \mathrm{~cm}$ increased from $0 \%$ in the untreated controls to a high of $68 \%$ in M.26 at $-27^{\circ} \mathrm{C}$. B. 9 had the least area affected, $20 \%$, and was the only rootstock to have significantly less area affected than M.26. Less than $40 \%$ of the xylem area had browning at $10 \mathrm{~cm}$ at the coldest temperature tested. An increase in phloem browning was not observed until a temperature of $-21{ }^{\circ} \mathrm{C}$, but the degree of browning did not differ between rootstocks at temperatures above $-27^{\circ} \mathrm{C}$. Differences in rootstocks occurred at a temperature of $-27^{\circ} \mathrm{C}$ when G.11 had a greater degree of browning than M.26, G.30, and P.2 but a similar level as B.9. Cambial browning did not increase with decrease in temperature until $-27^{\circ} \mathrm{C}$ when it was generally slight and not variable with rootstock (data not shown). However, severe browning occurred sporadically and was typically next to a lateral bud.

Exposing trunks to freezing temperatures in fall did not affect shoot growth the next spring (data not shown), so the $\mathrm{LT}_{50}$ could not be determined. Trees were pruned back to $10 \mathrm{~cm}$ where less internal browning occurred than at $25 \mathrm{~cm}$ and were pruned back to a point where an insufficient amount of injury occurred to affect shoot growth (Steinmetz, 1937).

Expt. 4. Shoot growth was decreased by exposing root tissue to temperatures of -10 to $-18^{\circ} \mathrm{C}$ with significant mortality at $-18^{\circ} \mathrm{C}$ in M.26, B.9, P.2, and G.30 (Fig. 2). G.935 had the greatest survival at $-18^{\circ} \mathrm{C}$. G. 41 was not tested at $-18{ }^{\circ} \mathrm{C}$ but had good survival of $-15^{\circ} \mathrm{C}$. Relative shoot growth did not differ between 
Experiment 3

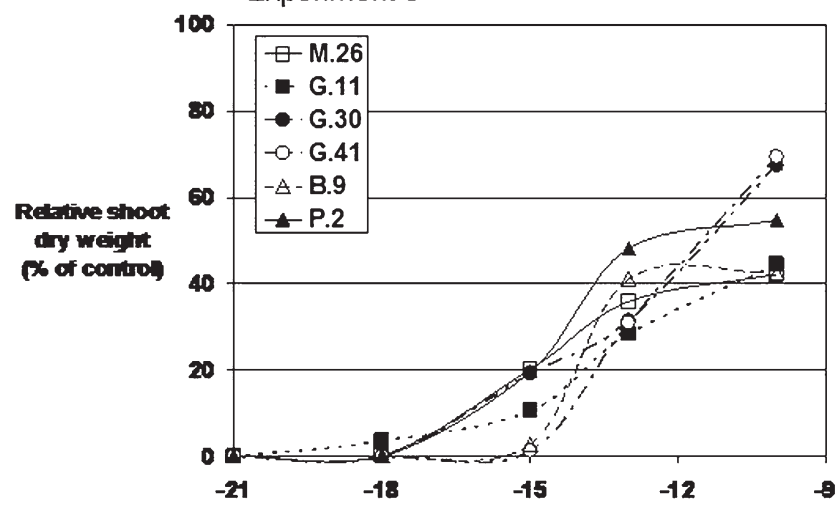

Experiment 4

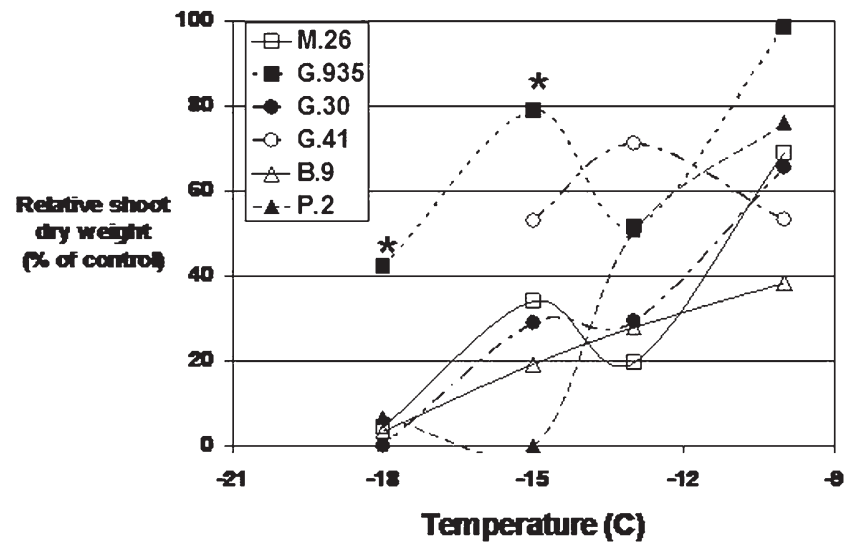

Fig. 2. Relative shoot growth of apple rootstocks following exposure of whole trees to temperatures of -10 to $-21{ }^{\circ} \mathrm{C}$ in Expt. 3 and -10 to $-18{ }^{\circ} \mathrm{C}$ in Expt. 4. Shoot growth is expressed as a percentage of the untreated control for each rootstock. *Significant difference from M.26.

Table 3. Internal browning rating in the trunk below the soil level and external browning of the root system $1 \mathrm{~d}$ after exposure of whole trees to freezing temperatures in February. ${ }^{z}$

\begin{tabular}{lccccccc}
\hline Root & \multicolumn{7}{c}{ Temperature $\left({ }^{\circ} \mathrm{C}\right)$} \\
\cline { 2 - 8 } stock & Control & -10 & -13 & -15 & -18 & -21 & -24 \\
\hline M.26 & 1.4 & 2.5 & 1.7 & 3.1 & 3.1 & $3.0 \mathrm{~b}^{\mathrm{y}}$ & 2.8 \\
G.30 & 1.7 & 2.3 & 2.8 & 3.1 & 3.0 & $2.8 \mathrm{~b}$ & 2.6 \\
G.11 & 1.7 & 2.3 & 2.2 & 2.2 & 3.4 & $2.7 \mathrm{~b}$ & 2.8 \\
G.41 & 1.4 & 2.7 & 3.0 & 2.5 & 2.9 & $2.3 \mathrm{~b}$ & 1.8 \\
B.9 & 2.0 & 3.2 & 2.0 & 4.1 & 3.3 & $4.0 \mathrm{a}$ & 2.6 \\
P.2 & 1.5 & 1.5 & 2.3 & 2.1 & 4.1 & $4.0 \mathrm{a}$ & 2.3 \\
$P^{\mathrm{x}}$ & NS & NS & NS & NS & NS & 0.0040 & NS
\end{tabular}

Root system

$\begin{array}{llllllll}\text { M.26 } & 1.4 \mathrm{~b} & 2.7 & 2.8 & 3.6 & 4.3 \mathrm{~b} & 5.0 & 5.0\end{array}$

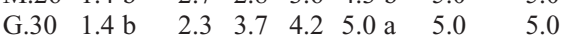

G.11 $1.0 \mathrm{~b} \quad 3.5 \quad 3.8 \quad 4.6 \quad 4.8$ a $\quad 5.0 \quad 5.0$

G.41 1.0 b $\quad 3.3 \quad 4.0 \quad 4.1 \quad 4.9$ a $\quad 5.0 \quad 5.0$

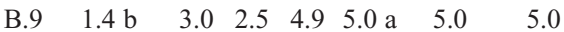

$\begin{array}{llllllll}\text { P. } 2 & 2.3 \text { a } & 2.7 & 3.3 & 4.6 & 5.0 \text { a } & 5.0 & 5.0\end{array}$

$\begin{array}{llllllll}P & 0.0133 & \text { NS } & \text { NS } & \text { NS } & 0.0236 & \text { NS } & \text { NS }\end{array}$

${ }^{2}$ Browning was measured at the lower $3 \mathrm{~cm}$ of the shank using a rating scale of 0 to 5 with 0 indicating no browning and 5 indicating dark brown.

${ }^{y}$ Means separation by LSMEANS, 5\% level of significance. Means followed by the same letter are not significantly different.

${ }^{x}$ Analysis of variance $P$ value for the main effect of rootstock at each temperature.

$\mathrm{NS}=$ nonsignificant. rootstocks after exposure to -10 and $-13{ }^{\circ} \mathrm{C}$. After exposure to $-15^{\circ} \mathrm{C}$, G.935 had similar relative shoot growth as $\mathrm{G} .41$ but was greater than M.26, G.30, P.2, and B.9 $(P \leq 0.01)$. G.41 and other rootstocks had a similar relative shoot growth as M.26 at $-15{ }^{\circ} \mathrm{C}$. G.935 had greater relative shoot growth than other rootstocks after exposure to $-18{ }^{\circ} \mathrm{C}(P \leq$ $0.01)$, whereas other rootstocks were similar to M.26. The $\mathrm{LT}_{50}$ varied from $-11.9^{\circ} \mathrm{C}$ in M.26 to $-18.8{ }^{\circ} \mathrm{C}$ in G.935 (Table 1). The $\mathrm{LT}_{50}$ of G.41 could not be estimated but was likely below $-15^{\circ} \mathrm{C}$.

\section{Discussion}

Injurious and lethal soil temperatures occur periodically in colder regions where apples are grown (Czyncsyk and Holubowicz, 1984; Quamme and Brownlee, 1997; Wildung et al., 1973). For successful planting in regions that have cold winters, apple rootstocks should have as much cold-hardiness as M.26, one of the hardiest of the Malling series (Cummins and Aldwinkle, 1974). Rootstocks tested in this study, G.41, G.11, G.30, B.9, and P.2, had root tissue cold-hardiness comparable to M.26. G.935 was the only rootstock to have greater root hardiness than M.26. Coldhardiness of B.9 and P.2 in relation to hardiness of M.26 was similar to previous
Table 4. Xylem and phloem browning rating following exposure of trunks to freezing temperatures in December. ${ }^{\mathrm{z}}$

\begin{tabular}{lllllll}
\hline Root & \multicolumn{6}{c}{ Temperature $\left({ }^{\circ} \mathrm{C}\right)$} \\
\cline { 2 - 7 } stock & Control & -15 & -18 & -21 & -24 & -27 \\
\hline M.26 & 1.5 & 1.2 & 2.0 & $2.0 \mathrm{a}^{\mathrm{y}}$ & $2.2 \mathrm{a}$ & $4.0 \mathrm{a}$ \\
G.30 & 0.8 & 1.4 & 1.5 & $1.8 \mathrm{ab}$ & $2.3 \mathrm{a}$ & $3.3 \mathrm{a}$ \\
G.11 & 1.2 & 1.0 & 1.2 & $1.2 \mathrm{bc}$ & $1.8 \mathrm{ab}$ & $2.8 \mathrm{ab}$ \\
B.9 & 1.0 & 1.0 & 1.3 & $1.0 \mathrm{c}$ & $1.3 \mathrm{~b}$ & $1.0 \mathrm{c}$ \\
P.2 & 0.8 & 1.0 & 0.7 & $1.0 \mathrm{c}$ & $1.3 \mathrm{~b}$ & $2.0 \mathrm{bc}$ \\
$P^{\mathrm{x}}$ & NS & NS & NS & 0.0265 & 0.0055 & 0.0004 \\
& & & & & &
\end{tabular}

\begin{tabular}{lllllll}
\multicolumn{7}{c}{ Phloem } \\
M.26 & 0 & 0 & 0 & 0.8 & 0.0 & $0.8 \mathrm{~b}$ \\
G.30 & 0 & 0 & 0 & 0.0 & 0.7 & $0.8 \mathrm{~b}$ \\
G.11 & 0 & 0 & 0 & 1.0 & 1.7 & $2.6 \mathrm{a}$ \\
B.9 & 0 & 0 & 1 & 0.8 & 1.5 & $1.5 \mathrm{ab}$ \\
P.2 & 0 & 0 & 0 & 0.0 & 0.3 & $0.0 \mathrm{~b}$ \\
$P$ & NS & NS & NS & NS & NS & 0.0125
\end{tabular}

${ }^{z}$ Browning was measured at a height of $25 \mathrm{~cm}$ above the soil line using a rating scale of 0 to 5 with 0 indicating no browning and 5 indicating dark brown.

${ }^{\mathrm{y}}$ Means separation by LSMEANS, 5\% level of significance. Means followed by the same letter are not significantly different.

${ }^{x}$ Analysis of variance $P$ value for the main effect of rootstock at each temperature.

$\mathrm{NS}=$ nonsignificant.

reports (Czyncsyk and Holubowicz, 1984; Quamme and Brownlee, 1997). Controlled cold-hardiness studies with most of the Geneva rootstocks are lacking, but in field trials, G.16 and G.30 had greater survival than M.26 or B.9 after a cold event (Robinson et al., 2007). G.41 also had good survival after a cold event (Robinson and Hoying, 2004) but had inconsistent cold-hardiness in these studies. Performance of G.41 was better in Expt. 4 than in Expts. 2 and 3. G.41 trees in Expt. 4 were 1 year older with a more extensive root system than in the previous two experiments, so better root growth may have contributed to the greater hardiness in Expt. 4. Root coldhardiness in G.11 was tested in only one experiment and was similar to M.26 and B.9.

The $\mathrm{LT}_{50}$ for M.26 root tissues ranged from -11.9 to $-14.1{ }^{\circ} \mathrm{C}$, which is similar to the reported cold temperature tolerance of -10 to $-14{ }^{\circ} \mathrm{C}$ based on root tissue browning and tree survival in controlled studies (Embree, 1988; Privé and Embree, 1997; Quamme and Brownlee, 1997; Wildung et al., 1973) and under field conditions (Czyncsyk and Holubowicz, 1984). G.935 had the lowest $\mathrm{LT}_{50}$, which ranged from -16 to $-19^{\circ} \mathrm{C}$. The $\mathrm{LT}_{50}$ for $\mathrm{G} .41$ was inconsistent in the different experiments, but when trees had a welldeveloped root system like in Expt. 4, the $\mathrm{LT}_{50}$ was lower than for M.26 indicating that the size of the root system may also contribute to cold-hardiness. G.41 trees in Expt. 3 had sparse roots. The $\mathrm{LT}_{50}$ of other rootstocks was generally similar to M.26 except for G.30 in Expt. 4 when it was $-15^{\circ} \mathrm{C}$.

In addition to root tissues, the belowground portion of the trunk also suffered cold temperature injury, which may have contributed to the reduction in shoot growth and 
mortality. However, shoot growth was more strongly correlated with browning of the root system than with browning in the belowground portion of the trunk as measured in Expt. 3. B.9 and P.2, which had less aboveground trunk injury than M.26 in December, had greater belowground browning in February. It is not clear if the hardiness that occurs in aboveground portions of trees can extend into the belowground portions, which have limited exposure to fluctuating and severe temperatures.

Apple trees are susceptible to fall freeze events during the acclimation stage (Quamme et al., 2010), a process that varies with rootstock (Domoto et al., 2001; Embree and McRae, 1991; Forsline, 1983). M.26 sustained little damage from temperatures as cold as $-30{ }^{\circ} \mathrm{C}$ in December in a previous study (Embree, 1988) but exhibited severe xylem browning in this study at $-27^{\circ} \mathrm{C}$. Trees in our experiment were stored at $1{ }^{\circ} \mathrm{C}$ rather than outdoors at colder temperatures, which may have limited the ability to acclimate to severe temperatures. Previous exposure to temperatures can determine the level of cold-hardiness in both root and stem tissue (Pellet, 1971). Cold-hardiness in the aboveground tissues of G.935 in October was similar to M.26, but belowground xylem was slightly less hardy than M.26. M.26 and P.2 acquire hardiness slightly earlier than B.9 when based on leaf drop and loss of chlorophyll (Elving et al., 1993). In this study, B.9 and P.2 were hardier than M.26 in December. G.11 had slightly greater xylem hardiness than M.26 but less phloem hardiness, which may indicate slower hardening (Quamme et al., 1972). Much of the rootstock is protected by the soil, but a portion remains exposed to air temperatures, particularly during the acclimation phase in fall when snow cover is lacking. In Maine, typical minimum air temperature from 15 Oct. to 15 Dec. ranged from -11 to $-18^{\circ} \mathrm{C}$. Trunks of rootstocks tested in this study would likely survive these temperatures but could suffer injury at temperatures below $-24{ }^{\circ} \mathrm{C}$, partic- ularly when conditions occur that slow the acclimation process.

G.935 is from a cross of 'Ottawa 3', which is rated as cold-hardy (Embree, 1988; Privé and Embree, 1997; Quamme and Brownlee, 1997), and 'Robusta 5', which is hardier than M.26 in winter but loses cold-hardiness faster in spring (Forsline, 1983; Wildung et al., 1973). G.30, G.41, and G.11 also have 'Robusta 5' as one parent but a Malling rootstock as the other.

Results of this study indicate that G.11, G.30, B.9, and P.2 have root tissue coldhardiness similar to M.26, but G.935 has greater cold-hardiness than M.26. Coldhardiness of G.41 was inconsistent but usually as good as M.26. Rootstocks tested in this trial would likely survive where M.26 has a good history of survival. G.935 is recommended for areas that experience injuriously cold soil temperatures.

\section{Literature Cited}

Autio, W., T. Robinson, B. Black, T. Bradshaw, J. Cline, R. Crassweller, C. Embree, E. Hoover, S. Hoying, K. Iungerman, R. Johnson, G. Lang, M. Parker, R. Perry, G. Reighard, J. Schupp, M. Stasiak, and M. Warmund. 2010. Performance of 'Fuji' and 'McIntosh' apple trees after 10 years as affected by several dwarf rootstocks in the 1999 NC-140 apple rootstock trial. J. Amer. Pom. Soc. 59:202-214.

Caprio, J. and H. Quamme. 1999. Weather conditions associated with apple production in the Okanagan Valley of British Columbia. Can. J. Plant Sci. 79:129-137.

Cummins, J. and H. Aldwinkle. 1974. Breeding apple rootstocks. HortScience 9:13-19.

Czyncsyk, A. 1979. Effect of M.9, B.9 and M.26 rootstocks on growth, fruiting, and frost resistance of apple trees. Fruit Sci. Rep. 6:143152.

Czyncsyk, A. and T. Holubowicz. 1984. Hardy, productive apple tree rootstocks used in Poland. Compact Fruit Tree 17:19-31.

Domoto, P., W. Autio, G. Brown, D. Ferree, P. Hirst, C. Mullins, and J. Schupp. 2001. Blackheart injury in 'Golden Delicious', 'Jonagold', 'Empire', and 'Rome Beauty' apple trees on five rootstocks in the $1990 \mathrm{NC}-140$ cultivar/ rootstock trial. J. Amer. Pom. Soc. 55:146-153.
Elving, D., I. Schecter, and A. Hutchinson. 1993. The history of the Vineland (V.) apple rootstocks. Fruit Varieties Journal 47:52-58.

Embree, C. 1988. Apple rootstock cold hardiness evaluation. Compact Fruit Tree 21:99-105.

Embree, C. and K. McRae. 1991. An exploratory study of reciprocal apple rootstock and scion hardiness with two methods of assessment. HortScience 26:1523-1525.

Forsline, P. 1983. Winter hardiness of common New York apple varieties and rootstocks as determined by artificial freezing. New York State Hort. Soc. Proc. 128:20-42.

Pellet, H. 1971. Comparison of cold hardiness levels of root and stem tissue. Can. J. Plant Sci. 51:193-195.

Privé, J.P. and C. Embree. 1997. Freezing media affect cooling rate and regrowth of KSC 28 apple rootstocks. Can. J. Plant Sci. 77:469-471.

Quamme, H. and R. Brownlee. 1997. Cold hardiness evaluation of apple rootstocks. Acta Hort. 451:187-193.

Quamme, H., A. Cannon, D. Neilsen, J. Caprio, and W. Taylor. 2010. The potential impact of climate change on the occurrence of winter freeze events in six fruit crops grown in the Okanagan Valley. Can. J. Plant Sci. 90:85-93.

Quamme, H., C. Stushnoff, and C. Weiser. 1972. The relationship of exotherms to cold injury in apple stem tissues. J. Amer. Soc. Hort. Sci. 97: 608-613.

Robinson, T., L. Anderson, W. Autio, B. Barritt, J. Cline, W. Cowgill, R. Crassweller, C. Embree, D. Ferree, E. Garcia, G. Greene, C. Hampson, K. Kosola, M. Parker, R. Perry, T. Roper, and M. Warmund. 2007. A multilocation comparison of 'Geneva 16', 'Geneva 41' and 'M.9' apple rootstocks in North America. Acta Hort. 732:59-65.

Robinson, T., G. Fazio, H. Aldwinkle, and S. Hoying. 2005. High-density orchards, dwarfing rootstocks more popular. The Fruit Grower News 42:24-26.

Robinson, T. and S. Hoying. 2004. Performance of elite Cornell-Geneva apple rootstocks in longterm orchard trials on growers farms. Acta Hort. 658:221-229.

Steinmetz, F.H. 1937. A histological evaluation of low temperature injury to apple trees. Me. Agr. Expt. Sta. Bull. 388.

Wildung, D., C. Weiser, and H. Pellet. 1973. Cold hardiness of Malling clonal apple rootstocks under different conditions of winter soil cover. Can. J. Plant Sci. 53:323-329. 